\title{
PEMBERDAYAAN IBU RUMAH TANGGA NELAYAN MELALUI PELATIHAN DIVERSIFIKASI PRODUK PERIKANAN DAN KELEMBAGAAN DI KELURAHAN MALABERO KOTA BENGKULU
}

\section{EMPOWERMENT OF FISHERMEN HOUSEWIVES THROUGH TRAINING OF FISHERY PRODUCT DIVERSIFICATION AND INSTITUTION IN THE MALABERO OF BENGKULU CITY}

\author{
Oleh: \\ Hari Laksamana ${ }^{1}$, Ferry Ro 'is ${ }^{2}$, Deri Syahputra ${ }^{2}$, Alfita Shirat Firdausiyah ${ }^{1}$, Reswita ${ }^{3}$ \\ ${ }^{1}$ Jurusan Sosial Ekonomi Pertanian Fakultas Pertanian Universitas Bengkulu \\ ${ }^{2}$ Jurusan Agroekoteknologi Fakultas Pertanian Universitas Bengkulu \\ ${ }^{3}$ Dosen Jurusan Sosial Ekonomi Pertanian Fakultas Pertanian Universitas Bengkulu \\ Email: harilaksamana411@gmail.com
}

\begin{abstract}
Malabero in Teluk Segara Bengkulu City is one of the villages mostly located in the coastal area and facing directly to beach or ocean. Most of the people work as fishermen who depend on their catch in the sea. This is quite a concern for the academics in seeing a phenomenon where there are still problems and opportunities that can be developed and at this time has not been developed by the fishing community. The problems and opportunities are the quality of products produced through the economic activities of the community in the form of fishery products. It can be happen and can't be separated from human resource problem that exist in coastal area in managing natural potency and manage effort properly. To provide solutions to these problems it is important for students as intellectual generation to implement creative economic empowerment for the community, especially housewives in Malabero Village. Activities undertaken in this activity are the provision of new business groups and institutional strengthening for target communities, providing training in the scope of entrepreneurship in the field of fishery processing, packaging training in accordance with standards for products in the area. The implementation of this activity for the community benefit consists of knowledge development, management and of course in utilizing the existing resources in the coastal region as a potential economic sector in a sustainable.
\end{abstract}

Keywords: empowerment, housewives of fishermen, coastal areas

\section{PENDAHULUAN}

Kota Bengkulu sebagai Ibu Kota Provinsi secara geografis terletak di pesisir barat Pulau Sumatera Negara Kesatuan Republik Indonesia. Berdasarkan letak geografisnya, Kota Bengkulu mempunyai lingkungan pantai yang berhadapan dengan gelombang kuat dan dapat menimbulkan erosi alami pantai atau abrasi pantai. Selanjutnya luas wilayah Kota Bengkulu yaitu $14.452 \mathrm{~km}^{2}$ dan panjang pantai $17,6 \mathrm{~km}^{2}$ dengan luas perairan laut $12.6720 \mathrm{~m}$. Letak strategis Kota Bengkulu di pantai barat Sumatera dan menghadap ke Samudera Hindia berdampak positif terhadap kekayaan hasil perikanan laut atau dengan 
kata lain yaitu memiliki potensi ekonomi yang cukup besar di sektor perikanan (DKP, 2014).

Kota Bengkulu memiliki potensi perairan laut teritorial sebesar 46145 ton per tahun dan potensi perairan laut zona ekonomi eksklusif (ZEE) sebesar 80071 ton per tahun dengan total jumlah nelayan 3756 orang. Dengan potensi laut yang cukup besar ini, sudah semestinya sektor kelautan dan perikanan mendapat prioritas pengembangan utama. Namun pada kenyataannya masih banyak ditemukan permasalahan yang dihadapi para nelayan selingkup Kota Bengkulu, khususnya pada pelaku usaha yakni nelayan di Kelurahan Malabero Kecamatan Teluk Segara Kota Bengkulu (BPS, 2013).

Kelurahan Malabero Kecamatan Teluk Segara Kota Bengkulu merupakan salah satu kelurahan yang sebagian besarnya berada pada wilayah pesisir yang berhadapan langsung dengan pantai atau lautan. Dalam kesehariannya sebagian besar masyarakat bekerja sebagai nelayan dan menggantungkan hidupnya dengan hasil tangkapan di laut. Hal ini cukup menjadi perhatian bagi kalangan akademisi dalam melihat sebuah fenomena dimana masih terdapat permasalahan serta peluang-peluang yang dapat dikembangkan dan pada masa ini belum dikembangkan oleh masyarakat nelayan. Diantara permasalahan dan peluang tersebut adalah kualitas produk yang dihasilkan melalui kegiatan industri kreatif atau rumahan hasil olahan perikanan yang tentunya dapat dikembangkan dengan diberikannya sentuhan manajemen serta teknologi dan inovasi dalam membuatnya selanjutnya juga belum adanya kelembagaan yang baik bagi masyarakat nelayan yang dapat memfasilitasi masyarakat dalam pengembangan pengetahuan SDM masyarakat nelayan dalam pengolahan hasil perikanan laut.

Sehingga dari permasalahan diatas dapat dilaksanakan suatu kegiatan pemberdayaan yang berfokus pada penguatan kelembagaan serta transfer pengetahuan kepada masyarakat nelayan yang dalam hal ini yakni ibu rumah tangga nelayan dengan harapan bahwa kaum ibu-ibu rumah tangga nelayan lebih memiliki peluang besar sebagai para pelaku usahausaha pengolahan hasil perikanan di lingkungan nelayan dibandingkan dengan kaum lelaki yang bertugas sebagai nelayan atau pencari ikan di laut. Adapun pada dasarnya, ide yang dilaksanakan tersebut tentu dilakukan dengan konsep penyuluhan, pendampingan serta pelatihan yang mengarah pada konsep minapolitan yang merupakan konsep pembangunan ekonomi kelautan dan perikanan berbasis wawasan yang berdasarkan prinsip-prinsip terintegrasi, efisiensi, peningkatan kualitas dan akselerasi/percepatan yang ditujukan kepada pembangunan sumber daya masyarakat setempat dalam mengelola dan memanfaatkan sumber daya alam.

Adapun tujuan pemberdayaan ini tentunya untuk memberdayakan ibu rumah tangga nelayan dalam menigkatkan pengembangan produk olahan hasil laut, manajemen kelembagaan, produksi dan pemasaran hasil olahan perikanan tangkap nelayan, membuat suatu kelompok usaha baru (KUB) desa yang memperhatikan unsur IPTEK berbasis minapolitan untuk menuju blue economy masyarakat pesisir serta meningkatkan kesejahteraan masyarakat pesisir melalui pencerahan informasi dan IPTEK untuk mengembangkan kewirausahaan masyarakat.

Dengan konsep dan tujuan tersebut tentu diharapkan akan memberikan efek yang baik bagi aspek ekonomi dan sosial masyarakat setempat sehingga dapat menumbuhkan dan mengembangkan kemandirian ekonomi masyarakat kecil skala mikro, menambah kualitas daya saing produk yang tinggi dalam pasar yang lebih luas dan menjadikan sektor perikanan sebagai sektor utama penggerak ekonomi regional atau wilayah tersebut. Hingga pada akhirnya perwujudan dari resolusi Blue Economy dapat terealisasi pada bentuk 
kesejahteraan sosial-ekonomi masyarakat di wilayah pesisir tersebut atau Kelurahan Malabero Kecamatan Teluk Segara Kota Bengkulu.

\section{METODE PENGABDIAN}

Metode pelaksanaan pada Program Kreativitas Mahasiswa-Pengabdian Kepada Masyarakat (PKM-M) ini yaitu metode PALS (Participatory Action and Learning System) yang memiliki beberapa prinsip dasar menurut Linda Mayouk dalam Reswita dkk (2015) yaitu; 1) menempatkan masyarakat di desa sasaran sebagai objek maupun subjek kegiatan; 2) pelaksanaan program menggunakan berbagai pendekatan; 3) pelaksanaan program berfokus pada kepentingan dan kebutuhan masyarakat; 4) program tersebut mengandung unsur pemberdayaan masyarakat, pemecahan masalah, pengembangan wilayah; 5) pelaksanaan kegiatan-kegiatannya bersifat sistemik, mencerdaskan dan merangsang aktivitas masyarakat sasaran kegiatan.

Prinsip dasar tersebut selanjutnya dilakukan melalui beberapa langkah kegiatan. Pertama yakni menjalin koordinasi dengan pihak kelurahan dan tokoh masyarakat. Selanjutnya yaitu dengan membuat dan menyebarkan undangan kepada masyarakat sasaran yakni ibu-ibu rumah tangga nelayan di Kelurahan Malabro. Lebih lanjut yaitu dengan menjalin kerjasama dengan akademisi/dosen Unib dan pihak Pemerintahan Kota Bengkulu melalui Dinas Koperasi dan UKM Kota Bengkulu untuk memberikan pengarahan tentang permodalan UKM dan pencerahan pra-koperasi yang kedepannya direncanakan akan di legalkan dengan badan hukum. Adapun pelaksanaannya yaitu dengan menyalurkan informasi atau transfer pengetahuan dalam bentuk materi, sosialisasi dan pelatihan kepada masyarakat sasaran dengan membuat forum formal dan semi-formal dilapangan yang berisikan materi atau informasi terkait kegiatan PKM-M yang dilaksanakan.

Pada aspek pelatihan dalam hal ini tim PKM-M menitik beratkan pada beberapa jenis pelatihan yaitu pelatihan pembuatan produk-produk yang dapat dibuat dan dikembangkan melalui pengolahan hasil perikanan tangkap, pelatihan pengemasan yang sesuai standar, pelatihan penguatan kelembagaan kelompok usaha baru yang dibentuk dalam penyampaian atau pelatihan perkoperasian serta diskusi-diskusi nonformal dengan masyarakat sasaran saat kegiatan pelatihan berlangsung.

Selanjutnya pada aspek pendampingan IPTEK yang dilakukan oleh tim pelaksana PKM-M ini yaitu dengan melakukan pelatihan yang sudah terlaksana 3 kali pertemuan dalam agenda pelatihan serta diskusi. Melalui kegiatan tersebut juga terjadi komunikasi yang baik sehingga terjadinya transfer informasi baik informasi yang bersifat baik bagi masyarakat sasaran maupun informasi bagi mahasiswa pelaksana PKM-M dalam mengembangkan pola pikir ilmiah. Melalui pendampingan ini juga diharapkan masyarakat mampu menerapkan manajemen yang baik bagi usaha yang dijalankannya, selanjutnya mahasiswa pelaksana PKM-M juga dapat menyalurkan ide-idenya serta belajar dengan masyarakat di lapangan.

\section{HASIL DAN PEMBAHASAN}

Pelaksanaan Program Kreativitas Mahasiswa-Pengabdian Kepada Masyarakat (PKM-M) ini di awali dengan koordinasi dengan pihak pemerintahan desa dan kota, selanjutnya rapat perdana tim pada tanggal 10 April 2017 untuk menyiapkan sosialisasisosialisasi kegiatan kepada masyarakat sasaran. Adapun pelaksanaan yang dilaksanakan 
pada tanggal 16 mei 2017 di Aula Kantor Kelurahan Malabero ini dihadiri oleh Kepala Dinas Koperasi dan UKM Kota Bengkulu sebagai salah satu mitra tim pelaksana dalam pelaksanaan PKM-M, selanjutnya dihadiri oleh Bapak Lurah Malabero, tokoh masyarakat serta para masyarakat sasaran yakni ibu-ibu rumah tangga nelayan di Kelurahan Malabero. Adapun kegiatan yang terlaksana pada pelaksanaan PKM-M ini yaitu terlaksananya pelatihan atau sosialisasi kelembagaan bagi masyarakat sasaran kegiatan, dalam hal ini bekerjasama dengan dinas koperasi untuk menjelaskan tentang kelembagaan koperasi, membentuk kelompok usaha baru (KUB) yang difasilitasi untuk menjadi badan hukum koperasi, terlaksananya pelatihan penganekaragaman produk olahan perikanan laut, pelatihan pengemasan dengan standarisasi dan desain yang baik serta manajemen pengolahan yang sesuai standar higienitas yang baik.

\section{Sosialisasi dan Pelatihan Kelembagaan Perkoperasian Bagi Kelompok Usaha Baru (KUB) yang Dibentuk}

Pelaksanaan pelatihan kelembagaan koperasi bagi masyarakat sasaran yang telah digabung dalam kelompok usaha baru ini dilakukan di Aula Kantor Kelurahan Malabero yang dibuka oleh Bapak Lurah dan dilanjutkan dengan materi dari pihak Dinas Koperasi dan UKM Kota Bengkulu serta diskusi-diskusi dalam pembentukan lembaga atau keorganisasian bersama tim pelaksana PKM-M. Pada saat diskusinya terdapat beberapa pertanyaan yang keluar dari masyarakat sasaran kegiatan yang selanjutnya dijawab oleh pembicara dan mahasiswa pelaksana PKM-M. Pada kesempatan ini juga dibentuk kelompok usaha baru (KUB) yang diberi nama kelompok minapolitan sejahtera dengan prospek kedepannya melalui kerjasama/mitra dengan instansi terkait akan dibentuk menjadi koperasi. Melalui kegiatan jenis ini diharapkan masyarakat sasaran memiliki pandangan yang baik terhadap suatu kelompok usaha yang sangat penting dalam menguatkan kegiatan ekonomi masyarakat sekitar melalui pengoptimalan pengolahan potensi wilayah pesisir tersebut.
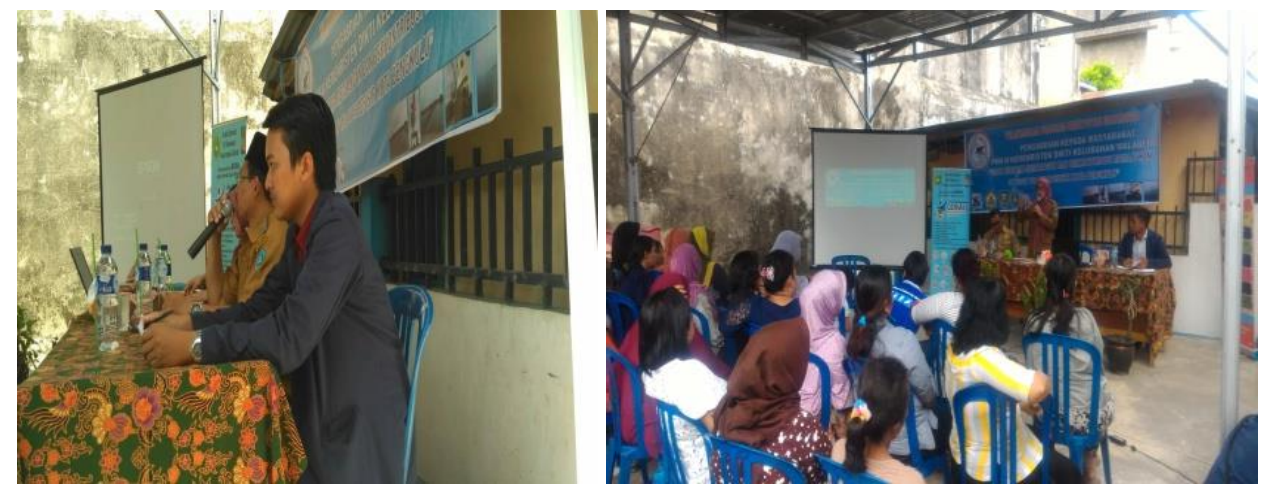

Gambar 1. Pelaksanaan pelatihan kelembagaan koperasi

\section{Pelatihan Diversifikasi Produk Perikanan Laut Serta Pelatihan Pengemasan}

Pada pelaksanaan yang terlaksana pada tanggal 23 Mei 2017 ini menghasilkan beberapa produk hasil pelatihan, diantaranya yaitu ikan beledang crispy original dan sambal balado, abon udang gurih, abon ikan tuna camkoha, salai ikan beledang, kemudian ikan dan cumi kering yang kesemuanya produk tersebut diolah dan dikemas dengan baik sesuai standar di pasaran. Adapun menurut Khamidi (2012) diversifikasi produk ini bertujuan untuk meningkatkan volume penjualan pada kegiatan suatu perusahaan. 
Pelatihan ini langsung menggunakan sumber daya yang ada pada wilayah pesisir tersebut yakni ikan dan udang halus yang didapatkan dari para nelayan sebagai bahan baku produk. Bahan baku tersebut diolah dengan berbagai campuran bumbu sehingga dapat diubah menjadi produk yang lebih memiliki nilai dipasaran. Untuk menambah nilai dipasaran tersebut tentu dalam hal ini diberikan sentuhan teknologi yang baik dalam pengemasan, dimana pengemasan telah menggunakan alat bantu yakni handseller serta sebelumnya juga masyarakat sasaran telah diberikan pencerahan informasi tentang bagaimana desain kemasan yang baik. Diantaranya yaitu yang membawa unsur komposisi, tanggal produksi, baik digunakan sebelum, berat bersih serta desain yang menarik yang dapat menggambarkan suatu produk. Selanjutnya melalui desain kemasan tersebut diharapkan juga dapat memberikan daya tarik bagi konsumen untuk mengkonsumsi suatu produk yang dihasilkan oleh masyarakat sasaran kedepannya.

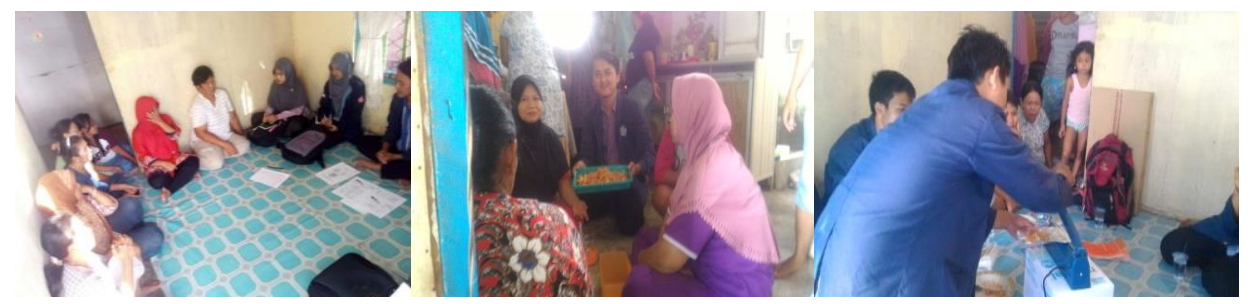

Gambar 2. Pelatihan pembuatan produk-produk perikanan yang potensial, diskusi kelembagaan dan pelatihan pengemasan.

\section{Evaluasi Kegiatan PKM-M}

Terlaksananya PKM-M ini telah terhitung mulai pada tahapan awal sampai akhir yakni mulai tanggal 10 April 2017 sampai dengan akhir juli 2017. Sehingga pada saat ini dapat dibuat bentuk evaluasi dari pelaksanaan program tersebut. Dimana diketahui saat sebelum memulai program tim pelaksana melakukan penelitian kecil tentang persepsi masyarakat sasaran terhadap PKM-M dan pengetahuan masyarakat sasaran tentang cakupan kewirausahaan dalam bidang perikanan di wilayah pesisir tersebut dan pengetahuan tentang kelembagaan atau dalam hal ini perkoperasian. Untuk itu di dapat hasil yang dapat disajikan pada diagram batang berikut:

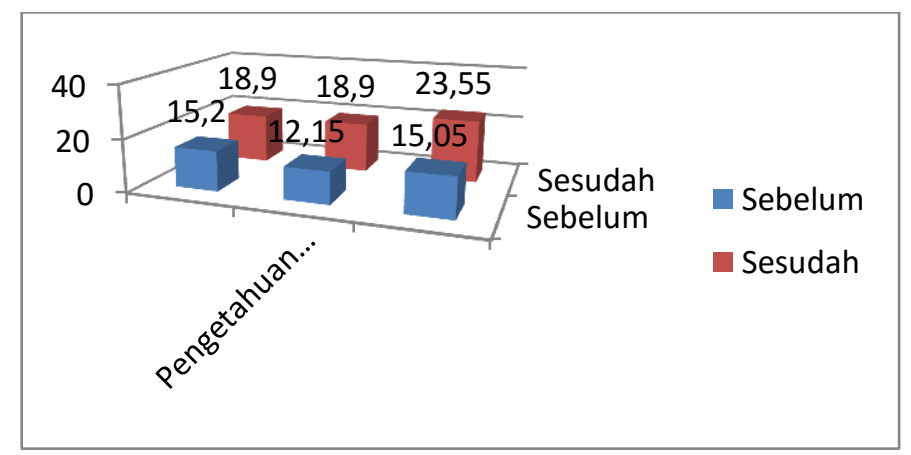

Gambar 3. Tingkat signifikansi peningkatan pengetahuan masyarakat sasaran

Melalui gambar diagram tersebut dapat dijelaskan bahwa dalam segi minat masyarakat mengikuti kegiatan PKM-M meningkat dari saat sebelum dan sesudah pelaksanaan kegiatan, artinya dalam hal ini kegiatan PKM-M memiliki prospek keberlanjutan yang baik dan dapat dilaksanakan lebih lanjut pada kelompok usaha baru yang dibentuk tersebut. Selanjutnya pada segi pengetahuan terhadap aspek-aspek 
kewirausahaan masyarakat mengalami peningkatan pengetahuan mulai dari angka 12,15 menjadi 18,9, pada segi pengetahuan kelembagaan naik dari 15,05 menjadi 23,55. Hal ini tentu dapat menjadi indikasi bahwa kegiatan PKM-M telah berhadil memberikan transfer informasi pengetahuan dan teknologi-teknologi terapan yang dapat diaplikasikan oleh kelompok usaha baru yang dibentuk. Sehingga kedepannya dapat memberikan implikasi atau dampak yang baik bagi kualitas SDM di wilayah pesisir dalam pengoptimalan pengelolaan sumber daya yang ada di wilayah pesisir tersebut.

\section{KESIMPULAN DAN SARAN}

\section{Kesimpulan}

Kegiatan PKM-M pada masyarakat sasaran yakni ibu rumah tangga nelayan di Kelurahan Malabero ini mendapat respon yang positif oleh masyarakat sasaran, segenap tokoh masyarakat, pihak kelurahan dan instansi-instansi pemerintahan serta pihak media lokal Provinsi Bengkulu. Adapun hasil yang dicapai pada pelaksanaan ini yakni penyampaian pelatihan kelembagaan koperasi, pelatihan kewirausahaan yang bergerak pada pengolahan sumber daya lokal yaitu perikanan laut, pengemasan serta desain kemasan. Selanjutnya juga tercapainya kelompok usaha baru yang kedepan melalui kerjasama/mitra dengan instansi pemerintah akan dibentuk menjadi badan hukum koperasi secara legal.

\section{Saran}

Hasil pelaksanaan kegiatan ini tentunya dapat dikembangkan oleh masyarakat menjadi produk khas Kota Bengkulu dan mendapatkan dukungan lebih dari pihak terkait untuk pengembangan lebih besarnya.

\section{DAFTAR PUSTAKA}

BPS, 2013, Produksi dan Nilai Produksi Perikanan Laut Kota Bengkulu Tahun 2012, BPS, Provinsi Bengkulu.

Dinas Kelautan dan Perikanan, 2014, Aneka Olahan dan Mutu Hasil Perikanan, DKP, Kota Bengkulu.

Khamidi, Sofwan, 2012, Pengaruh Diversifikasi Produk terhadap Penjualan (Studi Kasus pada Perusahaan Konveksi "Faiza Bordir" Bangil-Pasuruan), Fakultas Ilmu Administrasi Universitas Brawijaya, Malang.

Reswita, Satria P.U, Dewi Herlina, dan Efendi Zulman, 2015, Diversifikasi Produk Aren dalam Rangka Peningkatan Nilai Tambah Gula Aren sebagai Produk Unggulan Daerah Kabupaten Lebong, Dharma Raflesia Unib Tahun XIII, Nomor 2 Desember 2015, ISSN 1693-8046. 